\title{
Minister Turnover, Critical Events, and the Electoral Calendar in Presidential Democracies
}

Marcelo Camerlo, University of Lisbon

Aníbal Pérez-Liñán, University of Pittsburgh

Under what conditions should presidents reshuffle the cabinet in response to critical events? We propose a model that underscores the interplay of political shocks, the electoral calendar, and constitutional term limits to explain cabinet turnover in presidential regimes. Our theory indicates that mass protests and media scandals represent critical events with different political dynamics. While presidents seeking reelection may choose to protect activist ministers in order to deliver successful policy outcomes, there is little to be gained in the long run from recurrent scandals. However, presidents discount long-term goals when elections are close and when they initiate a lame-duck period. We test those predictions using survival analysis with an original data set for 12 Latin American democracies between 1978 and 2007.

S tudies of presidential and parliamentary democracies have increasingly documented the use of cabinet reshuffles to address executive concerns about public approval, policy performance, and accountability (see Dowding and Dumont 2009, 2014). Incumbent governments often rearrange the cabinet in response to critical events such as sudden drops in popularity, scandals, or economic crises (Dewan and Dowding 2005; Dewan and Myatt 2007; Martínez-Gallardo 2014). This literature also indicates that the electoral calendar decisively shapes cabinet dynamics (Altman 2000; see also Kam and Indriðason 2005). Yet there is little comparative knowledge about why (and when) particular shocks affect portfolio allocation.

This article explains the timing of minister replacements in the context of presidential regimes. We argue that executive responses to critical events are shaped by the time horizons of presidents and ministers, which in turn are determined by the electoral calendar and by the possibility of presidential reelection. In addition, we show that strategic responses vary with the nature of critical events, as presidents and ministers react differently to crises when they pre- sent opportunities to expand public support and when they simply anticipate the dissolution of public trust.

A separation-of-powers system is an optimal institutional setting to explore this issue because presidents have considerable leeway to appoint and dismiss ministers, and because the duration of presidential administrations is independent from the duration of each cabinet. Our analysis shows that critical events have heterogeneous causal effects on minister duration, which depends on the nature of the shock and on the institutional context confronted by the executive.

In the first section we discuss the relationship between critical events and portfolio allocation. The second section presents a formal model of minister turnover in presidential regimes. The model generates four hypotheses about how the electoral calendar and constitutional rules mediate the impact of social protests and media exposés on cabinet stability. The third section introduces data and method. We use original data on minister tenure and political conflicts for 12 Latin American democracies in 1978-2007 and employ survival analysis to test the hypotheses. The fourth section in-

Marcelo Camerlo (mcamerlo@ics.ul.pt) is a researcher at ICS-University of Lisbon, Lisbon, Portugal, 1600-189. Aníbal Pérez-Liñán (asp27@pitt.edu) is associate professor at the University of Pittsburgh, Pittsburgh, PA 15260.

Data and supporting materials necessary to reproduce the numerical results in the article are available in the JOP Dataverse (https://dataverse.harvard.edu /dataverse/jop). Support for this research was provided by the Portuguese Foundation for Science and Technology (FCT), and by the Center for Latin American Studies and the Center for Global Studies at the University of Pittsburgh. An online appendix containing supplemental analyses is available at http://dx.doi/10.1086/681028.

The Journal of Politics, volume 77, number 3. Published online April 1, 2015. http://dx.doi.org/10.1086/681028

(C) 2015 by the Southern Political Science Association. All rights reserved. 0022-3816/2015/7703-0002\$10.00 
terprets the empirical results (the online appendix addresses further concerns about endogeneity). The last section summarizes our main conclusions. Our findings indicate that media scandals are likely to trigger minister turnover early in the presidential term, when the president has enough time to recover from a cabinet reshuffle, while mass protests are likely to trigger turnover late in the term, when the president cannot wait for controversial policies to deliver outcomes. However, these incentives are reversed when presidents confront term limits.

\section{PORTFOLIO ALLOCATION AND CRITICAL EVENTS}

Heads of government use portfolio allocation to craft legislative coalitions, in order to promote governability, and to revamp the cabinet, in order to confront critical events. Coalition cabinets are a classic theme in the literature on parliamentary democracies and in the more recent literature on presidentialism (see Chasquetti [2008] aand Martin and Stevenson [2001] for respective summaries). By contrast, the reallocation of cabinet portfolios in response to political shocks has received limited attention. ${ }^{1}$

While there is almost no cross-national evidence on the incidence of critical events on portfolio allocation (MartínezGallardo [2014] is an exception), Kam and Indriðason (2005) provide an analysis of minister turnover in five Westminster systems. Their study shows that prime ministers use cabinet reshuffles to maintain power, and that reshuffles are more likely when the prime minister's position deteriorates vis-àvis internal rivals. Students of the British case have also addressed this question. ${ }^{2}$ Dewan and Dowding (2005) argue that portfolios are used to confront declines in popularity resulting from policy failure, incompetence, or scandals. Their results suggest that the reallocation of portfolios may preserve and even improve government popularity. Berlinski, Dewan, and Dowding (2010) conceive portfolio allocation as a prime minister's tool to promote better performance, removing incompetent ministers and retaining competent ones. They show that a minister's tenure depends not only on his or her own accomplishments but also on other colleagues' performance (see also Dewan and Myatt 2010; Dowding and Kang 1998; Fischer et al. 2006). Dewan and Myatt (2007) develop a formal model in which scandals are positively related to policy activism. Thus, the presence of scandals is not necessarily an indicator of corruption but the result of political reactions against a proactive minister.

1. For a comprehensive review of the literature on minister turnover see Fischer et al. (2012).

2. On the determinants of presidential portfolio allocation, see Escobar-Lemmon and Taylor-Robinson (2005, 2009).
In this model, the prime minister can use portfolio reallocation to protect ministers from such attacks and encourage them to take risks. ${ }^{3}$

Strategic incentives documented in the British case also emerge in presidential democracies. Like prime ministers, presidents are concerned with approval rates (critical to promote their policy agendas and to secure votes at the next election), with the tenure of their ministers (who may shirk to advance their own political careers), and with the threat of exogenous shocks (which may undermine support for the government). However, presidential democracies have three distinctive institutional features.

First, presidential constitutions establish fixed terms in office for the chief executive (Linz 1990), imposing a rigid timing to the quest for public support. The absence of regular dismissal procedures such as the vote of no confidence often makes presidents willing to adopt unpopular policies early in the term, in the expectation that voters will have enough time to update their beliefs about the administration's program and support the president at the next election (Stokes 2001).

Second, most presidential constitutions impose term limits. Some Latin American democracies ban presidential reelection altogether (Guatemala, Honduras, Mexico, and Paraguay), others allow reelection but not for consecutive terms (Chile, Costa Rica, El Salvador, Panama, Peru, and Uruguay), and some authorize a single consecutive reelection (Argentina, Bolivia, Brazil, Colombia, and Ecuador). Unrestricted reelection, a common feature in European democracies, is only allowed by Venezuela since 2009 and Nicaragua since 2014. Incentives to mobilize voter support may change considerably toward the end of the term if the chief executive is a lame duck (Besley and Coate 1995).

Third, presidential constitutions usually grant the chief executive great autonomy to appoint and dismiss ministers, creating a cyclical pattern of alignment between presidents and their cabinets. When presidents are popular and likely to be reelected, moral hazard problems are rare. There are no significant payoffs in going against strong presidents. On the contrary, when presidents are weak or cannot run for reelection, ministers' incentives to follow self-interested strategies are stronger than in parliamentary systems. Because the resignation of ministers has no immediate consequence for the survival of the government, members of a presidential coalition may simply abandon the cabinet (Altman 2000; Chasquetti 2008), and members of the ruling party

3. For another view of portfolio reallocation as a tool to improve policy making, see Huber and Martínez-Gallardo (2008) and Indriðason and Kam (2008). 
may build their own base of support as the party scrambles to find new leaders.

Given those institutional features, we argue that different political shocks will promote alternative strategic responses from presidents and their ministers. We consider two kinds of events: social protests and media scandals. Following Dewan and Myatt (2007), we interpret "social protests" as a challenge against active ministers. New policies introduce changes to the status quo, producing adherents and detractors. If policies prove to be successful in the long run, the government eventually consolidates the support of adherents and may even convince some detractors. Following Dewan and Dowding (2005) and Berlinski et al. (2010), we interpret "media scandals" as claims against illegal or reprehensible behavior related to corruption or abuse of power. Such accusations tend to enlarge the number of detractors but are unlike to capture new adherents. If proven true, the revelations will taint the credibility of the government and impose lasting political costs. Therefore, decisions to reshuffle the cabinet in response to protests or scandals may involve divergent considerations.

The consequences of presidential responses to protests or scandals are shaped by two additional factors, the electoral calendar and term limits. The "electoral calendar" determines the time left for the administration to deliver policy outcomes-or for investigators to prove officials guilty of corruption-before the end of the term. Rules about reelection alter career opportunities for both presidents and ministers. As Strøm (2000) has argued, presidents are better equipped to deal with problems of moral hazard than prime ministers. However, this advantage tends to vanish when they cannot run for reelection. In those circumstances, presidents will concentrate on their legacy, while ministers follow self-interested strategies in order to preserve their careers in the near future.

\section{CRISES AND TURNOVER IN PRESIDENTIAL SYSTEMS}

Consider a stylized model of minister turnover involving two actors, the president and a minister (for clarity in the exposition, we use the female pronoun for the president and the male pronoun for the minister). Confronted with protests against her policies or with scandals that compromise her administration, the president can dismiss the minister or retain him in office. In turn, the minister may resign or stay on the job. Such actions have consequences for the players in terms of public support, which ultimately defines their payoffs.

Each actor seeks to maximize a public support function that we generally describe as his or her political capital. For example, the president may seek to expand her share of the popular vote, $v_{P} \in[0,1]$. The minister may seek to build support among different constituencies, depending on whether he is an agent of the president, an independent party leader, the representative of an interest group, or member of an epistemic community. For generality, we represent his support function within the target group as $v_{M} \in[0,1]^{4}$

Both players potentially benefit from their partnership in the cabinet. Ministers help the president build a strong base of support by delivering policies valued by voters, mobilizing factions of the ruling party, or representing other parties in the ruling coalition. Let $v_{P}=e+\mu m$, where $e$ is the level of support independently commanded by the president, $m$ is the support independently commanded by the minister, and $\mu$ is the minister's contribution rate to the president's political capital (a fixed capacity determined by the minister's profile). Similarly, presidents contribute to their ministers' careers by offering them a prominent position from which they can shape policies and distribute resources. Thus, $v_{M}$ $=m+\pi e$, where $\pi$ is the president's contribution rate to the minister's political capital. In many presidential systems where ministers' careers depend on the president, the value of $m$ is quite small vis-à-vis $\pi e$ (Carreras 2013). ${ }^{5}$

In order to build political capital, the president and her ministers may prioritize long-term or short-term gains. Short-term strategies elicit an immediate response from citizens, while long-term actions require that players wait for payoffs to be realized. Players weight future payoffs according to $\phi_{i}$ and immediate payoffs according to $1-\phi_{i}$, where $i \in\{P, M\}$ identifies the player, and $0 \leq \phi \leq 1$ indicates how much deferred payoffs are valued vis-à-vis shortterm increases in public approval. ${ }^{6}$

\section{Protests versus scandals}

This setup allows for the identification of two distinct strategic games created by protests and media scandals. In the long run, activist ministers may deliver successful policy outcomes, attracting new voters to the president's coalition, while corrupt or divisive ministers may deliver new scandals, undermining public support. In the short run, however, the dismissal of activist cabinet members is functional to reorient policies and construct new electoral coalitions, while

4. Conceptualizing the support function in the $[0,1]$ interval facilitates identifying the relative size of the opposition as $1-v_{P}$.

5. Yet the literature has shown that presidential cabinets are not simply creatures of the president, especially when ministers are technocrats (Dargent 2014; Dominguez 1997).

6. Notice that $\phi$ is not a discount factor, because politicians may value future popularity at the time of an election more than current popularity in a nonelection year. 
the firing of ministers in the midst of a scandal is unlikely to seduce any additional voters.

G1 (protests). When the president appoints a team to address a pressing policy issue, she expects the new policy to yield success with probability $\sigma_{P}>0$. For the president, policy success represents an opportunity to attract voters outside her initial coalition. For a minister, it is an opportunity to extend his reputation. In the short run, however, dismissing a minister may provide immediate benefits by attracting some share of the opposition supporting the protests, $\omega(1-e-\mu m)$. A dismissal also involves costs, since the president will forgo the minister's contribution in the short run and the possibility of claiming credit for his policies in the future.

The first panel of figure 1 (G1) summarizes this situation in strategic form. If the president yields to the opposition, she secures a new level of support $e+\omega(1-e-\mu m)$. If the minister resigns, he withdraws his contribution, and the opposition interprets this outcome as a triumph over the administration. By contrast, if the president protects a minister and he stays in office, the president preserves her coalition intact in the short run and captures a new segment of the electorate of size $1-e-\mu m$ with probability $\sigma_{P}$ into the future. Similarly, the minister preserves his political capital and attracts a new following of size $1-m-\pi e$ with probability $\sigma_{M}{ }^{8}$ Payoffs are weighted according to the value players assign to the future; thus $v_{P}=\left(1-\phi_{P}\right)(e+\mu m)+$ $\phi_{P}\left(e+\mu m+\sigma_{P}(1-e-\mu m)\right)$, and $v_{M}=\left(1-\phi_{M}\right)(m+\pi e)+$ $\phi_{M}\left(m+\pi e+\sigma_{M}(1-m-\pi e)\right)$.

G2 (scandals). The second panel of figure 1 represents the situation in which the administration is besieged by media exposés. The president expects further disclosures to emerge with probability $\kappa_{P}$ (the minister assesses this risk with probability $\kappa_{M}$ ). Public condemnation could cost the president her electoral base and the minister his credibility. However, presidents and their ministers may also derive benefits from activities tied to the scandal, such as campaign funding or patronage, represented by $s_{P}$ and $s_{M}$, respectively. ${ }^{9}$

7. This argument also applies to protests that can be mollified by sacrificing a minister who is not in charge of the contested policy area. For example, if trade unions challenge fiscal policy and the president co-opts union leaders by offering them the labor ministry, she will still relinquish some labor policies over the long run.

8. We subscript sigma to allow for the possibility that presidents and ministers will benefit differently from a policy, creating the risk of agency loss.

9. Where $s_{i} \geq 0$. Note that $s_{M}-s_{P}$ reflects the moral hazard incurred by the president.
G1. Administration Confronts Protests

$\mathrm{M}$

\begin{tabular}{c|c|c|}
\multicolumn{1}{c}{ P Stay } & Resign \\
\cline { 2 - 3 } & $e(1-\omega)+\omega(1-\mu m)$ & $e$ \\
& \\
Protect & $m$ \\
\cline { 2 - 3 } & $\begin{array}{l}\varphi_{P} \sigma_{P}+e\left(1-\varphi_{P} \sigma_{P}\right) \\
+\omega m\left(1-\varphi_{P} \sigma_{P}\right)\end{array}$ \\
$\begin{array}{c}\varphi_{M} \sigma_{M}+m\left(1-\varphi_{M} \sigma_{M}\right) \\
+\pi e\left(1-\varphi_{M} \sigma_{M}\right)\end{array}$ & \\
& \\
\hline
\end{tabular}

G2. Administration Confronts Scandals

$\mathrm{M}$

\begin{tabular}{c|c|c|}
\multicolumn{1}{c}{ P Remove } & Stay & Resign \\
\cline { 2 - 3 } & $e$ & $e$ \\
& & \\
Protect & $m$ \\
\cline { 2 - 3 } & $\begin{array}{c}s_{P}+e\left(1-\varphi_{P} \kappa_{P}\right) \\
+\mu m\left(1-\varphi_{P} \kappa_{P}\right) \\
s_{M}+m\left(1-\varphi_{M} \kappa_{M}\right) \\
+\pi e\left(1-\varphi_{M} \kappa_{M}\right)\end{array}$ \\
\hline
\end{tabular}

Figure 1. Two games of cabinet removal

A strategy of damage control involves firing ministers perceived to be the source of scandals-a source of corruption, press leaks, or both-bearing a cost in the short run but minimizing costs over the long-run, since the president secures her electoral base $e$. If the minister resigns, the outcome is similar because the minister withdraws his contribution but the episode is closed. But if the president protects the minister and he stays in office, the president risks the collapse of the electorate's trust with probability $\kappa_{P}$ in the future. Thus $v_{P}=\left(1-\phi_{P}\right)\left(s_{P}+e+\mu m\right)+\phi_{P}\left(s_{P}+\left(1-\kappa_{P}\right)\right.$ $(e+\mu m))$. Similarly, the minister risks losing his base of support, and $v_{M}=\left(1-\phi_{M}\right)\left(s_{M}+m+\pi e\right)+\phi_{M}\left(s_{M}+\left(1-\kappa_{M}\right)\right.$ $(m+\pi e))$.

\section{Elections and time horizons}

Presidents and ministers need to mobilize public support in order to foster policy agendas at the present and to secure their careers in the future. The value players assign to future support depends on two conditions: the time left to the end 
of the term, and whether presidential reelection is allowed or banned. In order to represent the electoral calendar, we use $T$ to denote the proportion of the period left, with $T=1 \mathrm{in}$ dicating the moment after the inauguration and $T=0$ indicating the time of the next inauguration.

When presidential reelection is allowed and the administration has been just inaugurated $(T=1)$, the president values public support at the present as much as in the future, because she will need a stable base to secure reelection at $T$ $=0$. In this balanced intertemporal strategy, $\phi_{P}=1 / 2$. To the extent that ministers want to preserve their positions in government, their priorities are similar to the president's, and $\phi_{M}=1 / 2$. As the next election approaches (i.e., $T \rightarrow 0$ ), the president increasingly values the immediate electoral outcome and discounts long-run payoffs because a victory is absolutely necessary to remain in office; by the time of a reelection campaign, $\phi_{P}=0$. Ministers posed to profit from the president's reelection will embrace similar priorities. Thus, in the absence of term limits, both actors will weight future payoffs with function $\phi_{P}=\phi_{M}=T / 2$. This means that the president and her ministers will become more concerned about securing immediate public support as elections draw near.

By contrast, if presidential reelection is not allowed, the president will pursue public support for her policy agenda early in the term but will discount deferred payoffs, since term limits will make public support less relevant toward the end of her administration. Thus, at $T=1, \phi_{P}=0$. The literature indicates that toward the end of the term, lame-duck presidents are mostly concerned about their legacies (Anderson 2010; Murphy and Stuckey 2002). Boosting approval rates in the short run is not a priority, but securing a place in history is; thus, at $T=0, \phi_{P}=1$. It follows that when the president confronts term limits, she weights future payoffs with function $\phi_{P}=1-T$.

Because in this case ministers cannot hang on to the president's coattails, their priorities will differ from the chief executive's. Early in the term, a strong political base is critical to retain influence over policy and to compete in the succession contest; late in the term, it will be needed to secure a successful role in later administrations. Therefore, by contrast to lame-duck presidents ministers will seek to balance short-term and long-term priorities, such that $\phi_{M}=$ $1 / 2$ throughout the term.

\section{Empirical implications}

We find the equilibria for G1 and G2 under two conditions, when the president can run for reelection and when she confronts term limits, substituting $\phi_{i}$ with the proper func- tion in each case and using a straightforward Nash equilibrium concept.

In game G1, ministers confronting protests never have incentives to resign. ${ }^{10} \mathrm{~A}$ president running for reelection will remove the minister from office if

$$
2(\omega(1-e)-\mu m(1+\omega))>T \sigma_{P}(1-e-\mu m) .
$$

Because $T=0$ at the end of the term, this equilibrium condition implies

H1A. When reelection is allowed, protests are more likely to promote minister turnover if they occur late in the term than early in the term.

By contrast, a president facing term limits will remove a minister if

$$
T \sigma_{P}(1-e-\mu m)>\left(\sigma_{P}-\omega\right)(1-e-\mu m)+\mu m .
$$

Therefore,

H1B. When reelection is not allowed, protests are more likely to promote minister turnover early in the term than at the end of the term.

In game G2, a president seeking reelection in the midst of scandals is willing to remove a minister if

$$
T \kappa_{P}(e+\mu m)>2\left(\mu m+s_{P}\right) .
$$

This condition is mirrored by the minister's strategy, who will resign if

$$
T \kappa_{M}(m+\pi e)>2\left(\pi e+s_{M}\right) .
$$

It follows that:

H2A. When reelection is allowed, scandals are more likely to promote minister turnover early in the term than at the end of the term.

By contrast, a president confronting term limits will only react to exposés if

$$
\kappa_{P}(e+\mu m)>T \kappa_{P}(e+\mu m)+\mu m+s_{P} .
$$

This means that the president will have very few incentives to remove ministers early in the term and may only dismiss cabinet members if scandals emerge later in the administration. However, because the minister needs to

10. If the minister is indifferent with regard to outcomes, we assume the status quo will prevail, and he will stay in office. If the president retains a minister, his resignation requires that $m+\pi e>1+\pi e / \sigma_{M} \phi_{M}$, reflecting that the minister will prefer to stay in office despite protests. 
balance inter-temporal career goals, he will resign if

$$
\kappa_{M}(m+\pi e)>2\left(\pi e+s_{M}\right) .
$$

Notice that $T$ plays no role in this case, suggesting that a minister may resign at any point. Ministers have greater incentives to quit whenever more incriminating evidence is likely to emerge, when they command an independent following, when they are less dependent on the president, and when they do not profit from the activities producing the scandal. Thus,

H2B. When reelection is not allowed, scandals may promote minister turnover throughout the term. Although incentives for the president to remove ministers increase later in the period, incentives for ministers to resign are stable throughout the term.

Our four hypotheses make pointed predictions about the timing and conditions for ministerial exits, but they provide no expectation about the specific ministers departing from the cabinet. The availability of multiple portfolios allows presidents to engage in a diverse range of strategies. Presidents may delegate policy management to a single minister or to a technical team-and therefore retain or dismiss one individual or several to quell protests. They may trade some positions in the cabinet to appease protests targeting unrelated policy areas. They may punish ministers they suspect to be corrupt or ministers they suspect to be leaking information to the press (or both). When forced to replace cabinet members, presidents may quietly dismiss an infringing official or they may theatrically reshuffle the whole cabinet. In turn, ministers may depart gracefully or bitterly, they may do so alone or drawing other colleagues with them. Thus, although individual exits are determined by many idiosyncratic factors, the timing of minister turnover in the cabinet will be shaped by exogenous shocks, political institutions, and the electoral calendar.

\section{DATA AND METHOD}

To test the four hypotheses we consider all ministers in office in 12 Latin American countries from 1978 (or the year of the democratic transition) to 2007. Our data set includes 74 administrations, about 1,230 portfolios, and 2,601 ministers. ${ }^{11}$ We analyze the length of time each minister occupied a

11. The cases are Argentina 1983-2007, Bolivia 1982-2007, Brazil 1985-2007, Chile 1990-2007, Colombia 1978-2007, Costa Rica 19782007, Ecuador 1979-2007, Mexico 1976-2007, Paraguay 1989-2007, Peru 1980-2007, Uruguay 1985-2007, and Venezuela 1979-2007. The data specific portfolio. Because we are interested in portfolio allocation during the administration's life cycle, we treat all ministers leaving office at the end of an administration as censored cases. The sample includes 1,618 exits during the term and 983 censored cases. The boundaries of administrations are defined by presidents' inauguration dates. ${ }^{12}$

Available cross-national information on protests and media scandals is quite limited in nature. In order to capture critical events, we relied on the Latin American Weekly Report (Lodola et al. 2007). A dichotomous indicator reflects whether protests affected an administration during each month of the study. Episodes of protest refer to contentious mobilization targeted at the government, and could involve looting and riots, roadblocks, invasions of land, occupations of public or private buildings, and marches and demonstrations. We observed an average of 31.8 protest events per administration for the whole period. Variable scandals measures the occurrence of a media exposé involving the president, members of the cabinet, the president's party, or the president's family or friends in any given month. Scandals may refer to administrative corruption, abuse of power, or character issues such as sex affairs. We observed an average of 16.6 scandal events per administration for the whole period. As the temporal repercussions of those events are hard to establish precisely, we coded all protests and scandals as interventions lasting for two months. Table A1 in the online appendix provides descriptive statistics for these variables.

Our hypotheses anticipate that presidents and ministers will respond strategically to those shocks, conditioned by the timing of the events and by whether reelection is allowed. Because the length of presidential terms range between four and six years, our variable calendar measures the proportion of days left to the constitutional date of the next inauguration, with 1 being the first day and 0 the last day of the administration (Altman 2000; Chasquetti 2008). This variable is substantively different from the duration of a particular minister in office; a minister may enter or leave the cabinet at any point in the electoral calendar. In turn, re-eligible indicates whether the president can run for immediate reelection. This dichotomous variable measures the incumbent's situation given the constitutional rule. For instance, Brazilian president Lula da Silva was re-eligible in his first term but

were gathered using the Keesing's World News Archive and multiple national sources.

12. We considered all presidents who took office and lasted for more than one week. We ignored interim presidents who were in office for less than a week, because the turnover of ministers in such cases (if new ministers are even appointed) does not provide meaningful information. 
not in his second one, because he confronted a two-term limit. We observed 12 re-eligible presidents out of 74 .

We consider two standard institutional attributes as control variables (Martínez-Gallardo 2012). Coalition registers whether the cabinet includes members of parties other than the president's (36 of 74 administrations). Minority reflects whether the president enjoys minority support in any of the legislative chambers (56 of 74). Two additional variables control for the macroeconomic context in any given year: inflation and economic growth (from the World Development Indicators). ${ }^{13}$

Individual ministers and cabinet portfolios present significant variation in terms of relevance and vulnerability. Although there is no conclusive evidence on how those characteristics influence their exposure to critical events, we have good reasons to suspect that not every cabinet member is equally vulnerable (Dull and Roberts 2009). We account for this heterogeneity in two ways. First, the analysis distinguishes three groups of portfolios based on their level of exposure to conflicts. Policy is a reference category for ministers in charge of macroeconomic management and specific policy areas such as Education, Health, and Labor, who are common targets of media scrutiny and mass demonstrations. Politics refers to portfolios like Interior or the Minister of the Presidency, who are fully engaged in domestic politics and have broad policy responsibilities. External identifies portfolios responsible for international issues, such as Foreign Affairs or Defense, which are not primarily involved in partisan politics or economic policy making and therefore are less likely to be targets of media investigations or social protests. In addition, first cabinet identifies individuals who arrived in office with the president. These ministers were appointed as the president's first choice and may therefore receive differential treatment when compared to others appointed later in the term.

Cabinet reshuffles are repeatable events (Kam and Indriðason 2005), and the frequency of cabinet reshuffles in the past may influence the conditions and incentives to remove cabinet members in the present. To control for the potential recurrence of cabinet turmoil as well as for the accumulated experience of removals within the administration, we include a variable that tallies the number of cumulative exits observed until the prior month.

Our sample only includes cabinets under democratic regimes, because the theory assumes that presidents and min-

13. Inflation and growth arguably affect presidential approval. Approval rates are relevant for cabinet survival (Camerlo and Pérez-Liñán 2015; Kam and Indriðason 2005), but unfortunately no comparative data on presidential approval are available (but see Carlin et al. 2012). isters are concerned about the independent effects of protests and scandals on electoral outcomes. However, transitional countries experienced different levels of democracy during this period. We assess the level of democracy by including the Polity 2 index that ranges from -10 (institutionalized autocracy) to +10 (institutionalized democracy) (Marshall et al. 2010).

Hypotheses 1 and 2 refer to the timing of individual exits from the cabinet. Therefore, we model the duration of individual ministers in office using a Cox proportional hazards model. Event history analysis allows us to estimate the probability that individual ministers will exit the portfolio at time $T$, accounting for censored observations as well as time-varying covariates. The semiparametric model does not assume any specific shape for the hazard function (Box-Steffensmeier and Jones 2004). In order to account for unobserved sources of heterogeneity, we estimate a frailty model in which latent frailties are assumed to vary by country.

All variables in the study are treated as time-varying covariates, which creates 118,037 observations for the 2,601 subjects analyzed. Variables are measured at monthly intervals for scandals and protests, quarterly for economic conditions, and daily for other traits. For instance, values for $m i-$ nority and coalition change on the date a new legislature takes office. The calendar variable is updated at least every 30 days. The dummies for protests and scandals are reset to 0 two months after an event.

\section{FINDINGS}

Table 1 presents the results of the analysis, with the effect of each covariate displayed as a hazard ratio. Model I, presented for reference, reports the unconditional effects of all variables, while models II through IV incorporate additional interaction terms. The first two models are estimated for all observations, while the remaining models are estimated for subsamples of re-eligible and non-re-eligible presidents.

The results in model I suggest that the presence of protests increases the hazard of minister turnover by about $13 \%$, while scandals increase that risk by about $28 \%$. These results are generally consistent with widespread intuitions about the impact of critical events on the survival of ministers. However, our theory makes specific predictions about how presidents should react to shocks, depending on the timing of the next presidential election and on their possibility of reelection.

In order to assess the conditional effects anticipated by our four hypotheses, model II includes interactions for protests $\times$ calendar and scandals $\times$ calendar, plus two triple interactions for protests $\times$ calendar $\times$ re-eligible and scandals $\times$ calendar $\times$ re-eligible. To achieve full specification, the 
Table 1. Proportional Hazard Models of Minister Duration

\begin{tabular}{|c|c|c|c|c|c|c|c|c|}
\hline & \multicolumn{4}{|c|}{ All Presidents } & \multicolumn{2}{|c|}{ Re-eligible } & \multicolumn{2}{|c|}{ Non-re-eligible } \\
\hline & \multicolumn{2}{|l|}{ I } & \multicolumn{2}{|l|}{ II } & \multicolumn{2}{|c|}{ III } & \multicolumn{2}{|c|}{ IV } \\
\hline & Hazard & (SE) & Hazard & (SE) & Hazard & (SE) & Hazard & (SE) \\
\hline Protests & $1.13^{\star}$ & $(.06)$ & .78 & $(.12)$ & 1.89 & $(.61)$ & .80 & $(.12)$ \\
\hline Scandals & $1.28^{\star}$ & $(.08)$ & $1.79^{*}$ & $(.28)$ & .88 & $(.29)$ & $1.82^{\star}$ & $(.29)$ \\
\hline Calendar & $2.07^{\star}$ & $(.30)$ & $2.07^{\star}$ & $(.36)$ & 1.52 & $(.84)$ & $1.74^{\star}$ & $(.30)$ \\
\hline Protests $\times$ Calendar & & & $1.76^{\star}$ & $(.40)$ & .45 & $(.26)$ & $1.66^{*}$ & $(.37)$ \\
\hline Scandals $\times$ Calendar & & & $.59^{\star}$ & $(.16)$ & 2.48 & $(1.48)$ & $.56^{\star}$ & $(.15)$ \\
\hline Minority & 1.10 & $(.08)$ & 1.09 & $(.08)$ & $.20^{*}$ & $(.07)$ & 1.09 & $(.09)$ \\
\hline Coalition & $1.19^{*}$ & $(.08)$ & $1.20^{*}$ & $(.08)$ & $2.10^{*}$ & $(.54)$ & $1.17^{\star}$ & $(.09)$ \\
\hline GDP growth & $.96^{*}$ & $(.01)$ & $.96^{*}$ & $(.01)$ & $.93^{*}$ & $(.01)$ & $.96^{*}$ & $(.01)$ \\
\hline Inflation & 1.00 & $(.00)$ & 1.00 & $(.00)$ & $.93^{*}$ & $(.01)$ & 1.00 & $(.00)$ \\
\hline Politics portfolio & $1.35^{\star}$ & $(.09)$ & $1.35^{\star}$ & $(.09)$ & 1.40 & $(.26)$ & $1.36^{*}$ & $(.10)$ \\
\hline External portfolio & $.81^{\star}$ & $(.06)$ & $.81^{\star}$ & $(.06)$ & 1.01 & $(.22)$ & $.77^{\star}$ & $(.06)$ \\
\hline First cabinet & $.78^{\star}$ & $(.06)$ & $.77^{\star}$ & $(.06)$ & $.62^{\star}$ & $(.15)$ & $.82^{\star}$ & $(.07)$ \\
\hline Cumulative exits & 1.00 & $(.00)$ & 1.00 & $(.00)$ & $.99^{*}$ & $(.01)$ & 1.00 & $(.00)$ \\
\hline Polity score & $.96^{\star}$ & $(.01)$ & $.97^{\star}$ & $(.01)$ & $.70^{\star}$ & $(.05)$ & .98 & $(.02)$ \\
\hline Reeeligible & .84 & $(.08)$ & .99 & $(.23)$ & & & & \\
\hline Calendar $\times$ Re-eligible & & & .71 & $(.29)$ & & & & \\
\hline Protests $\times$ Re-eligible & & & $2.66^{\star}$ & $(.89)$ & & & & \\
\hline Scandals $\times$ Re-eligible & & & $.32^{*}$ & $(.11)$ & & & & \\
\hline Protests $\times$ Calendar $\times$ Re-eligible & & & $.25^{\star}$ & $(.14)$ & & & & \\
\hline Scandals $\times$ Calendar $\times$ Re-eligible & & & $5.94^{*}$ & $(3.70)$ & & & & \\
\hline Wald $\chi^{2}$ & [13] 151.93 & & [20] 171.68 & & [14] 90.90 & & [14] 117.20 & \\
\hline Log likelihood & $-11,314.2$ & & $-11,303.6$ & & -888.4 & & $-9,874.8$ & \\
\hline Theta & $.207(.087)$ & & $.211(.088)$ & & $.018(.080)$ & & $.208(.088)$ & \\
\hline Observations & 118,037 & & 118,037 & & 13,860 & & 104,177 & \\
\hline Groups (countries) & 12 & & 12 & & 5 & & 12 & \\
\hline Subjects (ministers) & 2,601 & & 2,601 & & 341 & & 2,352 & \\
\hline Failures & 1,618 & & 1,618 & & 188 & & 1,430 & \\
\hline
\end{tabular}

Note. Entries are hazard ratios (standard errors in parentheses).

${ }^{*} p<.05$.

model also includes the set of related interactions: protests $\times$ re-eligible, scandals $\times$ re-eligible, and calendar $\times$ reeligible. The large number of interactions makes the results had to interpret, but some empirical insights can be gleaned directly from the table. First, the coefficient for protestswhich represents the effect of protests when the administration is coming to an end, and the president cannot be reelected-is not significant, but the estimate for protests $\times$ re-eligible suggests that this effect increases when the president can run for reelection. This result is consistent with hypotheses $1 \mathrm{~A}$ and $1 \mathrm{~B}$. Second, the coefficient for scandalsreflecting the impact of exposés when the administration is ending and the president cannot be reelected-is positive and significant. The interaction scandals $\times$ re-eligible sug- gests that this effect declines when the president can run for reelection. This pattern is consistent with hypotheses $2 \mathrm{~A}$ and 2B.

A nuanced interpretation of the results requires a systematic analysis of marginal effects. For convenience we split the sample in two groups-re-eligible and non-re-eligible presidents-in order to facilitate interpretation. ${ }^{14}$ Model III analyzes the effect of conflicts and the electoral calendar on

14. Separation of the sample into two subsamples presents an additional advantage. We examined the scaled Schoenfeld residuals through the Grambsch and Thernau test. While protest and calendar violate the proportionality assumption in model I and scandals and calendar do so in model II, none of them violates the assumption in model III, and only scandals appears to challenge the assumption in model IV. 
minister turnover when reelection is allowed. Model IV employs the same specification when reelection is banned. To interpret the results of these models, we compute marginal effects of protests and scandals for re-eligible and nonre-eligible presidents. Table 2 reports the hazard ratios at the extremes of the electoral calendar and the temporal intervals during which each variable produces a significant increase in the risk of cabinet turnover.

\section{Hypothesis $1 \mathrm{~A}$}

Model III examines minister turnover when reelection is allowed. An analysis of marginal effects, summarized in table 2, indicates that the conditional effect of protests is significant for the last $36 \%$ of the administration, with the hazard ratio rising from 1.41 (at $T=.36$ ) to 1.89 (at $T=0$ ). Thus, when reelection is allowed, protests increase the hazard of minister turnover toward the end but not at the beginning of the administration.

\section{Hypothesis $2 \mathrm{~A}$}

Scandals produce an opposite dynamic. Coefficients for scandals and its interaction with calendar are, when considered separately, statistically insignificant. However, the analysis of marginal effects for model III shows a significant effect for most of the first half of the term, with a hazard ratio that decreases from 2.19 (at $T=1$ ) to 1.40 (at $T=.51$ ). That is, scandals increase the risk of turnover by about $119 \%$ at the start of the administration and by $40 \%$ shortly before the midpoint in the term. In sum, when reelection is allowed, scandals promote minister turnover during the early days of the administration but not at the end.

Table 2. Conditional Effects on the Hazard of Turnover

\begin{tabular}{|c|c|c|c|c|}
\hline \multirow{2}{*}{$\begin{array}{l}\text { Reelection: } \\
\text { Calendar: }\end{array}$} & \multicolumn{2}{|c|}{ Allowed } & \multicolumn{2}{|c|}{ Banned } \\
\hline & $T=1$ & $T=0$ & $T=1$ & $T=0$ \\
\hline \multirow[t]{2}{*}{ Protests } & .85 & $1.89^{*}$ & $1.33^{\star}$ & .80 \\
\hline & \multicolumn{2}{|c|}{$\begin{array}{c}{[.36,0] \text { (late in }} \\
\text { the term) }\end{array}$} & \multicolumn{2}{|c|}{$\begin{array}{c}{[1, .68] \text { (early in }} \\
\text { the term) }\end{array}$} \\
\hline \multirow[t]{2}{*}{ Scandals } & $2.19^{\star}$ & .88 & 1.03 & $1.82^{*}$ \\
\hline & \multicolumn{2}{|c|}{$\begin{array}{c}{[1, .51] \text { (early in }} \\
\text { the term) }\end{array}$} & \multicolumn{2}{|c|}{$\begin{array}{c}{[.75,0] \text { (most of }} \\
\text { the term) }\end{array}$} \\
\hline
\end{tabular}

Note. Entries are conditional hazard ratios, based on models III and IV. Brackets indicate calendar intervals with significant effects $(p<.05)$. For instance, $[.75,0]$ indicates that protests significantly increase turnover during the last three-quarters of the term.

${ }^{*} p<.05$.

\section{Hypothesis $1 \mathrm{~B}$}

Model IV examines minister turnover when presidents cannot run for immediate reelection. Constitutive terms for protests shows nonsignificant estimates while the interaction with calendar positive and significant. In turns, the conditional effect of protests is significant from the inauguration of the term, with hazard ratios between 1.33 (at $T=1$ ) and 1.13 (at $T=.68)$. Hence, when reelection is banned, protests produce minister turnover at the beginning but not at the end of the term.

\section{Hypothesis 2B}

In model IV the main coefficient for media scandals is positive and significant, while the interaction of scandals and calendar has a negative and significant effect. As shown in table 2, scandals significantly increase turnover in the calendar range between .75 and 0 (the last day of the administration), with the hazard rate rising from 1.18 to 1.82 . Thus, when reelection is banned, scandals expand the risk of minister turnover for the last three quarters of the administration.

These estimates are strikingly consistent with our theory's predictions. Protests and scandals promote minister turnover, but their effects are moderated by term limits and by the electoral calendar in ways anticipated by our analytical model. We provide a graphic representation of these marginal effects using the metric of Cox regression coefficients in figure 2 (i.e., negative values indicate hazard ratios smaller than one). When immediate reelection is possible, protests increase the risk for ministers in the second half of the term (fig. 2.1) while scandals increase that risk early in the term (2.2); when reelection is not allowed, protests affect turnover during the first half of the term (2.3) while scandals do so for three quarters of the period (2.4).

Moving on to the control variables, results in table 1 show that Latin American coalition governments replace their ministers more often, while the effect of minority governments is generally insignificant. The results also indicate that a $1 \%$ increase in economic growth reduces the risk of minister turnover by between $4 \%$ and $7 \%$, while inflation has few discernible effects. In line with some of our previous insights, presidents seem more willing to protect ministers when they confront growing inflation and they face reelection. As expected, inaugural ministers have a lower risk of leaving office than those appointed later during the administration. Compared to ministers responsible for specific policy areas, ministers running political portfolios generally have a shorter tenure, while the opposite is true for ministers with competence over international issues. Results for the variable cumulative exits are nonsignificant except for model 


\section{Reelection Allowed (Model III)}

\subsection{Protests}

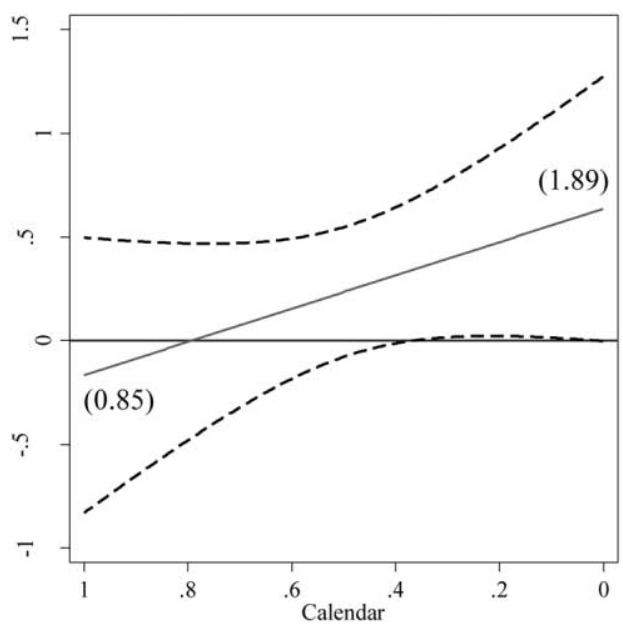

2.2. Scandals

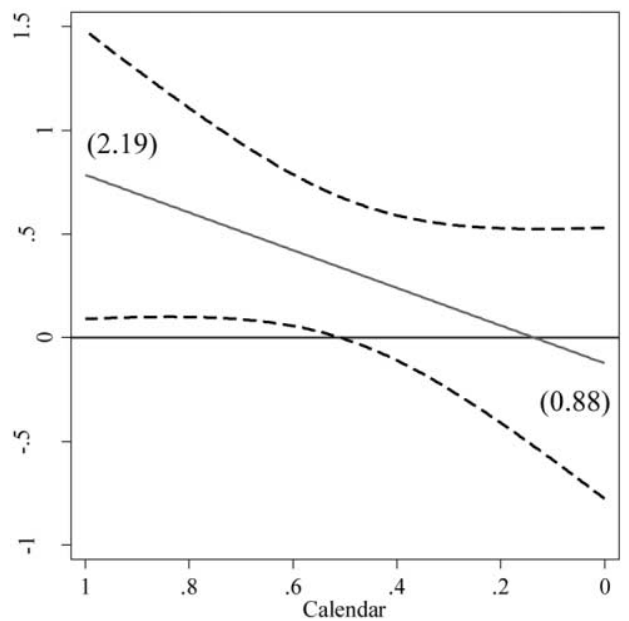

Reelection Banned (Model IV)

2.3. Protests

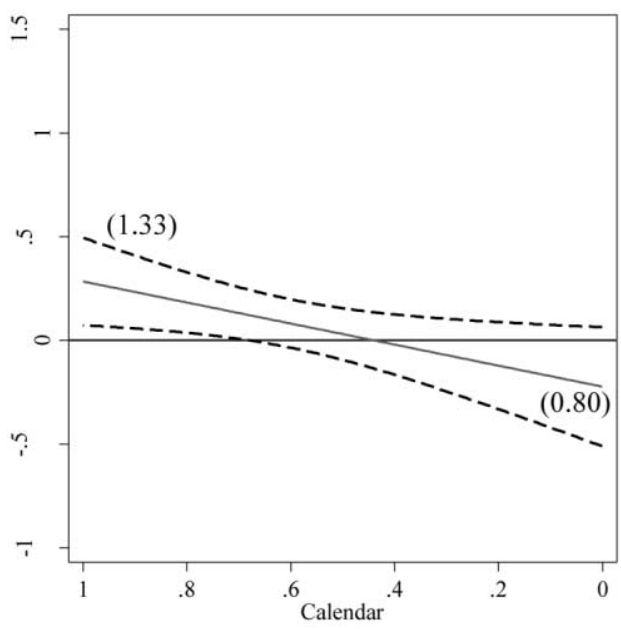

2.4. Scandals

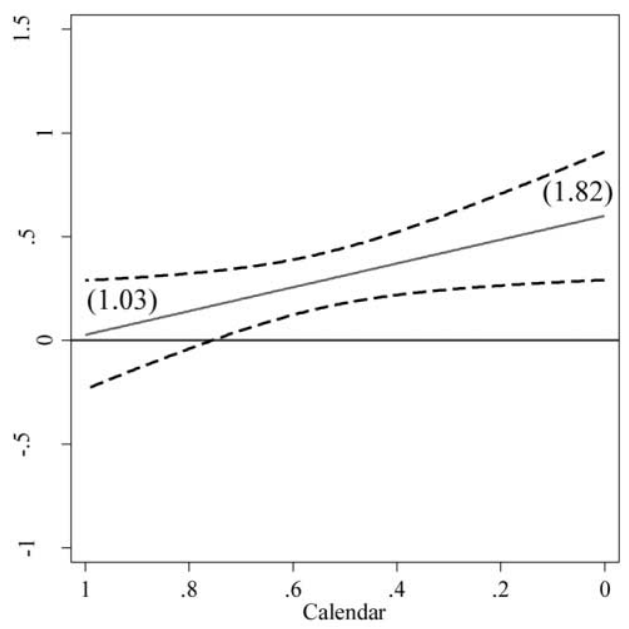

Figure 2. Lines reflect marginal effects for Cox regression coefficients in models III and IV. Dashed lines are $95 \%$ confidence interval. Calendar represents the countdown to the end of the term. Values in parentheses translate conditional coefficients into hazard ratios.

III, where the negative hazard ratio indicates that the experience of previous exits reduce the risk of future removals when presidents are re-eligible. Finally, results for the Polity index, suggest that higher levels of democracy produce a decreasing hazard rate for ministers.

\section{DISCUSSION AND CONCLUSIONS}

Our empirical findings for 12 Latin American countries support the predictions derived from the theoretical model: political shocks increase the risk of minister turnover, but their effects are conditioned by strategic considerations and institutional factors. If presidents aspire to reelection, they respond to media exposés by removing ministers early in the term, when there is enough time to clean the administration's image, and they respond to mass protests by removing ministers late in the term, when there is not enough time to implement controversial policies successfully. By contrast, presidents confronting term limits respond to protests early in the term and respond to scandals late in the term. Under term limits, however, members of a cabinet affected by exposés have greater incentives to withdraw from the govern- 
ment in order to protect their future political careers. Our main findings hold even after we account for the potential endogeneity of critical events (see the section on Estimation Concerns in the online appendix).

These complex effects underscore the importance of integrating lessons of presidential and parliamentary systems for the study of executive politics. Classic studies of cabinet dynamics focused on the formation and dissolution of parliamentary governments (e.g., Laver and Shepsle 1996). Yet over the past few years an emerging line of research has emphasized the study of cabinets during the governments' life cycle (Dowding and Dumont 2009; Huber and MartinezGallardo 2008; Indriðason and Kam 2008; Kam and Indriðason 2005). As part of this movement, recent studies have shown that critical events not only trigger the downfall of governments but also incite the exit of individual ministers (Berlinski et al. 2012; Dewan and Dowding 2005; Dewan and Myatt 2007).

Our study contributes to this literature by documenting two claims. First, "critical events" are a heterogeneous set of shocks with asymmetric causal effects. We have shown that media investigations and social mobilization affect cabinet stability differently. In the same vein, it is possible that different types of protests (e.g., those related to living conditions or to civil rights) will affect different types of portfolios, or that shocks of different nature (e.g., bursts of inflation or unemployment) will undermine ministers of different ideological persuasions. Unpacking this broad category, together with refinements related to the identification of the individual targets of these conflicts, is one of the pending tasks for studies of presidential and parliamentary systems.

Second, the impact of critical events is mediated by institutional conditions. Our findings suggest some distinctive lessons for studies of presidentialism. Over the past decade, comparative studies of presidential government focused on the formation of cabinets, either to explain minister profiles (Escobar-Lemmon and Taylor-Robinson 2005, 2009) or to explain the formation and collapse of interparty coalitions (Altman 2000; Amorim Neto 2006; Chasquetti 2008; Martínez-Gallardo 2012). Although early studies stressed the similarities of coalition politics under presidentialism and parliamentarism, scholars were cognizant of some unique political dynamics created by presidential constitutions, such as the "tyranny" of the electoral calendar (Altman 2000; Chasquetti 2008; Linz 1990). The results presented in this article underscore the relevance of term limits for the strategic behavior of political actors in the executive branch. Restrictions on reelection comprise a distinctive feature of presidential constitutions that cannot be ignored by future studies of cabinet politics in Latin America, the United States, and other separation-of-powers regimes.

\section{REFERENCES}

Altman, David. 2000. “The Politics of Coalition Formation and Survival in Multiparty Presidential Democracies: The Case of Uruguay, 19891999." Party Politics 6 (3): 259-83.

Amorim Neto, Octavio. 2006. "The Presidential Calculus: Executive Policy Making and Cabinet Formation in the Americas." Comparative Political Studies 39 (4): 415-40.

Anderson, Lisa. 2010. “The Ex-Presidents.” Journal of Democracy 21 (2): 65-78.

Berlinski, Samuel, Torun Dewan, and Keith Dowding. 2010. "The Impact of Individual and Collective Performance on Ministerial Tenure.” Journal of Politics 72 (2): 559-71.

Berlinski, Samuel, Torun Dewan, and Keith Dowding. 2012. Accounting for Ministers: Scandal and Survival in British Government, 1945-2007. Cambridge: Cambridge University Press.

Besley, Tim, and Stephen Coate. 1995. "Does Electoral Accountability Affect Economic Policy Choices? Evidence from Gubernatorial Term Limits." Quarterly Journal of Economics 110 (3): 769-98.

Box-Steffensmeier, Janet M., and Bradford S. Jones. 2004. Event History Modeling: A Guide for Social Scientists. Cambridge: Cambridge University Press.

Camerlo, Marcelo, and Aníbal Pérez-Liñán. 2015. “The Politics of Minister Retention: Technocrats, Partisans, and Government Approval." Comparative Politics 47 (3), forthcoming.

Carlin, Ryan E., Cecilia Martínez-Gallardo, and Jonathan Hartlyn. 2012. "Executive Approval Dynamics under Alternative Democratic Regime Types." In Douglas Chalmers and Scott Mainwaring, eds., Problems Confronting Contemporary Democracies: Essays in Honor of Alfred Stepan. Notre Dame, IN: University of Notre Dame Press, 203-26.

Carreras, Miguel. 2013. "Presidentes Outsiders y Ministros Neófitos: Un Análisis a Través del Ejemplo de Fujimori.” América Latina Hoy 64: 95-118.

Chasquetti, Daniel. 2008. Democracia, presidencialismo y partidos políticos en América Latina: Evaluando la "difícil combinación." Montevideo: Cauce Editorial.

Dargent, Eduardo. 2014. Technocracy and Democracy in Latin America: The Experts Running Government. New York: Cambridge University Press.

Dewan, Torun, and Keith Dowding. 2005. "The Corrective Effect of Ministerial Resignations on Government Popularity.” American Journal of Political Science 49 (1): 46-56.

Dewan, Torun, and David Myatt. 2007. "Scandal, Protection, and Recovery in the Cabinet." American Political Science Review 101 (1): 63-77.

Dewan, Torun, and David Myatt. 2010. "The Declining Talent Pool of Government." American Journal of Political Science 54 (2): 267-86.

Domínguez, Jorge, ed. 1997. Technopols: Freeing Politics and Markets in Latin America in the 1990's. University Park: Pennsylvania State University Press.

Dowding, Keith, and Patrick Dumont, eds. 2009. The Selection of Ministers in Europe: Hiring and Firing. London: Routledge.

Dowding, Keith, and Patrick Dumont, eds. 2014. The Selection of Ministers around the World. London: Routledge.

Dowding, Keith, and Won-Taek Kang. 1998. "Ministerial Resignations 1945-97.” Public Administration 76:411-29.

Dull, Matthew, and Patrick S. Roberts. 2009. "Continuity, Competence, and the Succession of Senate-Confirmed Agency Appointees, 19892009." Presidential Studies Quarterly 39 (3): 432-53. 
Escobar-Lemmon, Maria, and Michelle Taylor-Robinson. 2005. "Women Ministers in Latin American Government." American Journal of Political Science 49 (4): 829-44.

Escobar-Lemmon, Maria, and Michelle Taylor-Robinson. 2009. "Getting to the Top: Career Paths of Women in Latin American Cabinets." Political Research Quarterly 62 (4): 685-99.

Fischer, Jörn, Keith Dowding, and Patrick Dumont. 2012. "The Duration and Durability of Cabinet Ministers." International Political Science Review 33 (5): 505-19.

Fischer, Jörn, Andre Kaiser, and Ingo Rohfling. 2006. "The Push and Pull of Ministerial Resignations in Germany, 1969-2005.” West European Politics 29:709-35.

Huber, John, and Cecilia Martinez-Gallardo. 2008. "Replacing Cabinet Ministers: Patterns of Ministerial Stability in Parliamentary Democracies." American Political Science Review 102 (2): 169-80.

Indriðason, Indriði, and Christopher Kam. 2008. "Cabinet Reshuffles and Ministerial Drift." British Journal of Political Science 38 (4): 62156.

Kam, Christopher, and Indriði Indriðason. 2005. "The Timing of Cabinet Reshuffles in Five Westminster Parliamentary Systems." Legislative Studies Quarterly 30 (3): 327-63.

Laver, Michael, and Kenneth A. Shepsle. 1996. Making and Breaking Governments: Cabinets and Legislatures in Parliamentary Democracies. New York: Cambridge University Press.

Linz, Juan J. 1990. “The Perils of Presidentialism." Journal of Democracy 1 (1): 51-69.
Lodola, German, Andrea Castagnola, Yen-Pin Su, John Polga-Hecimovich, Juan Negri, Alicia Quebral, and Aníbal Pérez-Liñán. 2007. "Latin American Political Processes: Scandals, Protest, and Institutional Conflicts, 1980-2007." Electronic file. Department of Political Science, University of Pittsburgh.

Marshall, Monty, Ted Gurr, and Keith Jaggers. 2010. "POLITY IV Project: Political Regime Characteristics and Transitions, 1800-2009." http:// www.systemicpeace.org/polity/polity4x.htm (accessed October 15, 2013).

Martin, Lanny W., and Randolph Stevenson. 2001. "Government Formation in Parliamentary Democracies." American Journal of Political Science 45 (1): 33-50.

Martinez-Gallardo, Cecilia. 2012. "Out of the Cabinet: What Drives Defections from the Government in Presidential Systems?" Comparative Political Studies 45 (1): 62-90.

Martínez-Gallardo, Cecilia. 2014. "Designing Cabinets: Presidential Politics and Ministerial Instability." Journal of Politics in Latin America 6 (2): $3-38$.

Murphy, John M., and Mary E. Stuckey. 2002. "Never Cared to Say Goodbye: Presidential Legacies and Vice Presidential Campaigns." Presidential Studies Quarterly 32 (1): 46-66.

Pérez-Liñán, Aníbal. 2007. Presidential Impeachment and the New Political Instability in Latin America. Cambridge: Cambridge University Press.

Stokes, Susan C. 2001. Mandates and Democracy: Neoliberalism by Surprise in Latin America. Cambridge: Cambridge University Press.

Strøm, Kaare. 2000. "Delegation and Accountability in Parliamentary Democracies.” European Journal of Political Research 37 (3): 261-89. 